\title{
Luehea divaricata Martius et Zuccarini Is a Sensitive Species to Aluminum, Not Presenting Phytoremediation Potential
}

\author{
Gessieli Possebom ${ }^{1}$, Aline Soares Pereira ${ }^{1}$, Athos Odin Severo Dorneles ${ }^{2}$, Victória Martini Sasso ${ }^{1}$, \\ Liana Veronica Rossato ${ }^{1}$, Luciane Almeri Tabaldi ${ }^{1}$, Sabrina Dalla Corte Bellochio ${ }^{1}$, Jover da Silva Alves ${ }^{1}$, \\ Luana de Campos de Jesus $^{1} \&$ Katieli Bernardy ${ }^{1}$ \\ ${ }^{1}$ Federal University of Santa Maria, Santa Maria, Brazil \\ ${ }^{2}$ Federal University of Pelotas, Pelotas, Brazil \\ Correspondence: Gessieli Possebom, Department of Rural Engineering, Federal University of Santa Maria, Av. \\ Roraima, 1000, Santa Maria, Brazil. Tel: 55-55-991-686-390. E-mail: gessielip@hotmail.com
}

Received: December 10, 2017

Accepted: January 19, 2018

Online Published: February 15, 2018

doi:10.5539/jas.v10n3p265

URL: https://doi.org/10.5539/jas.v10n3p265

\begin{abstract}
The aim of this work was to evaluate the effect of different concentrations of aluminum (Al) on physiological and biochemical parameters of Luehea divaricata seedlings grown in a hydroponic system under greenhouse conditions to verify the possible tolerance to Al or phytoremediation potential of this species. Seeds of Luehea divaricata were placed to germinate in commercial substrate and after 30 days the seedlings were transferred to a hydroponic system with a complete nutrient solution, $\mathrm{pH}$ at $4.5 \pm 0.1$, with daily adjustment. After 20 days of acclimatization, homogenous plants were selected and transferred to a new nutrient solution (without phosphorus (P) and $\mathrm{pH}$ at $4.5 \pm 0.1$ ) with different concentrations of $\mathrm{Al}$ : $0,25,50,75$ and $100 \mathrm{mg} \mathrm{L}^{-1}$, each treatment being composed of 10 replicates of one plant each. The experiment was conducted in a completely randomized design. After seven days of exposure to the treatments, plants were collected for physiological and biochemical analyzes. Aluminum promoted a significant reduction in fresh and dry weight of roots, stems and leaves; in plant height; leaf number; leaf area; and pigment content. On the other hand, Al promoted an increase in lipid peroxidation and guaiacol peroxidase enzyme activity. Therefore, the presence of $\mathrm{Al}$ in the growth medium, for the studied conditions, altered significantly both physiological and biochemical parameters in Luehea divaricata seedlings, presenting a sensitive behavior to this element. Due to these characteristics, the studied species does not show phytoremediation potential.
\end{abstract}

Keywords: acidic soils, antioxidant enzymes, açoita-cavalo, lipid peroxidation

\section{Introduction}

Acidic soils, which occupy about 30\% of ice-free areas in the world (Brunner \& Sperisen, 2013), directly influence on plant development. A large proportion of these soils is covered by forests (Fao \& Iiasa, 2007). These soils are present in several parts of the world, including in Brazil, the state of Rio Grande do Sul being one where they appear more significantly (Abreu et al., 2003). This acidity promotes a decrease in plant growth due to aluminum (Al) toxicity, as well as low base saturation, and deficiency of phosphorus, calcium, magnesium and molybdenum (Poschenrieder et al., 2008).

Aluminum is the third most abundant element in Earth's crust, after oxygen and silicon. In acidic soils, where $\mathrm{pH}$ is less than or equal to 5.5, $\mathrm{Al}$ is able to solubilize itself and become possibly toxic to some plants (Singh et al., 2017). In addition, it is noteworthy that the effect of this toxicity on the root system is that it inhibits its growth, fixes phosphorus in forms which are less available in the soil and/or roots, and reduces root respiration (Gupta et al., 2013; Schmitt et al., 2016). Furthermore, it has the potential to interpose in enzymatic reactions, to promote oxidative stress, as well as to interfere in the absorption, transportation and utilization of other nutrients, inducing nutritional deficiency in the plant (Tabaldi et al., 2009; Dorneles et al., 2016; Singh et al., 2017).

Aluminum is not an essential element to plant growth, since it does not meet any essentiality criteria. However, under special conditions, from the element in the culture medium and depending on the species, $\mathrm{Al}$ it can induce an increase in plant growth and even produce other positive effects on growth. Moreover, physiological, 
molecular and biochemical mechanisms of Al tolerance in plants have been proposed to try to explain the tolerance presented by some plants to the excess of this metal (Foy et al., 1978; Sousa et al., 2016).

Unlike annual crops (Tabaldi et al., 2009; Carlin et al., 2012; Bojórquez-Quintal et al., 2014), little attention has been given to forest species, especially the native ones, in relation to their behavior in relation to $\mathrm{Al}$ (Alves et al., 2001; Brunner \& Sperisen, 2013). In synthesis, the effect of this element varies according to the studied species or even to the genotype within the same species. Forest species that are able to grow and complete their life cycle on acid soils rich in $\mathrm{Al}$ can be grown in these soils, which are often unsuitable for growing food or medicinal plants. Therefore, the selection of species of trees tolerant to Al toxicity may be an option for plant restoration in acidic soils and metal contaminated areas, besides being used as phytoremediation species.

The Luehea divaricata (Martius et Zuccarini) species, popularly known as açoita-cavalo in Brazil, is native to the state of Rio Grande do Sul (RS), belonging to the Malvaceae family (Carvalho, 2008). It is of great importance, especially in the Mixed Ombrophilous Forest of this state. Due to its easy adaptability, it is a target species for the recovery of degraded areas and reforestation. Its wood is widely used for construction, furniture and energy production, as well as medicinal uses (IBGE, 2012). Its vast use, along with its natural distribution in the soils of RS, suggests that the species could present a certain tolerance to Al and, therefore, have phytoremediation potential.

The previous selection of seedlings exposed to toxic concentrations of $\mathrm{Al}$ in a hydroponic system may provide adequate information about the survival capacity of the seedlings after their transplantation to the field. Thus, the objective of this study was to evaluate the effect of different concentrations of Al on physiological and biochemical parameters of Luehea divaricata seedlings grown in a hydroponic system to verify the possible tolerance or phytoremediation potential of this species.

\section{Method}

The experiments were carried out in the Plant Biotechnology Laboratory and in greenhouses belonging to the Biology Department of the Federal University of Santa Maria, RS. Seeds of Luehea divaricata were germinated in plastic trays with commercial substrate Plantmax and irrigated daily with a complete nutrient solution, keeping $\mathrm{pH}$ at $4.5 \pm 0.1$, with daily adjustment. The nutrient solution had the following composition (in $\mu \mathrm{M}$ ): 6090.5 of N; 974.3 of Mg; 4986.76 of Cl; 2679.2 of K; 2436.2 of Ca; 359.9 of S; 243,592 of P; 0.47 of Cu; 2.00 of $\mathrm{Mn} ; 1.99$ of $\mathrm{Zn} ; 0.17$ of Ni; 24.97 of B; 0.52 of Mo; 47.99 of $\mathrm{Fe}\left(\mathrm{FeSO}_{4} / \mathrm{Na}-\mathrm{EDTA}\right)$.

After 30 days, the initial growth period of the seedlings, 75 homogenous plants with the height of about $10 \mathrm{~cm}$ were transferred to trays in a hydroponic system, where they were fixed by means of sponges in polystyrene plates, for acclimatization. The same nutrient solution was used, with $\mathrm{pH}$ at $4.5 \pm 0.1$, with daily adjustment and constant aeration system. The volume of the trays was replaced daily and the solution changed every 3 days.

At 20 days of acclimatization, new homogeneous plants were selected, which were transferred to the final hydroponic system, in $1 \mathrm{~L}$ pots, with one plant each. In a new nutrient solution (without $\mathrm{P}$ and $\mathrm{pH}$ at $4.5 \pm 0.1$ ), five treatments were applied: $0,25,50,75$ and $100 \mathrm{mg} \mathrm{L}^{-1}$ of $\mathrm{Al}$, each consisting of 10 replicates. The experiment was conducted in a completely randomized design, the nutrient solution was replaced every two days, with daily replenishment and $\mathrm{pH}$ level adjusted at each replacement. After seven days of exposure to the treatments, the plants were collected for physiological and biochemical analyzes.

\subsection{Physiological Parameters}

For the physiological evaluations, four plants per treatment were collected, having their roots washed in distilled water, and then divided into leaves, stem and root system. It was determined the number of leaves, aerial part length (using a ruler graduated in millimeters), leaf area (with leaf area integrator), and fresh and dry weight of leaves, stems and roots. The parts were collected separately and immediately weighed in a digital scale to determine fresh weight. Then they were dried in an oven at $65{ }^{\circ} \mathrm{C}$ with forced ventilation until constant weight, and the appropriate dry weights were measured.

\subsection{Biochemical Parameters}

For the biochemical analyzes, six plants per treatment were collected and separated into leaves and roots. The material was washed with distilled water, immediately frozen in liquid nitrogen and then stored in a freezer at $-80{ }^{\circ} \mathrm{C}$ in order to maintain its characteristics. Chlorophylls $a$ and $b$ and carotenoids were extracted according to the method of Hiscox and Israelstan (1979) and estimated using the equation of Lichtenthaler (1987).

The lipid peroxidation was determined in the plants root system, according to the method of El-Moshaty et al. (1993). For the preparation of extracts for the determination of antioxidant enzymes activity, it was initially used 
the protocol of Zhu et al. (2004) to determine the enzyme activity, and later the protocol of Bradford (1976) to determine the concentration of proteins. The guaiacol peroxidase (POD) activity was determined according to Zeraik et al. (2008) and the superoxide dismutase (SOD) activity was determined according to the spectrophotometric method, described by Giannopolitis and Ries (1977).

\subsection{Tolerance Index}

The Al tolerance index was calculated according to Trannin et al. (2001), through Equation 1:

$$
T I=\frac{T D W_{A l}}{T D W_{c}} \times 100
$$

where, $T I=$ tolerance index; $T D W_{A l}=$ total dry weight in each concentration of aluminum; $T D W_{C}=$ total dry weight in control.

\subsection{Statistical Analysis}

Data normality and homogeneity of variances were tested through the Shapiro-Wilk and Bartlett tests, respectively, both using the Action-Excel Software. The data were submitted to variance analysis and tested by the $5 \%$ probability of error regression models, through the SISVAR Software (Ferreira, 2011). The graphics program used was SigmaPlot 12.5.

\section{Results}

\subsection{Analysis of Fresh and Dry Weight}

Based on tests of normality and homogeneity, the data showed to be normal and the variances are homogeneous. Tables 1 and 2 show the results of the analysis of variance for the physiological and biochemical parameters, demonstrating a significant effect at $5 \%$ of error probability in all study analyzes.

Table 1. Results of the analysis of variance for the physiological parameters in Luehea divaricata Martius et Zuccarini seedlings submitted to different aluminum concentrations

\begin{tabular}{lllllllllll}
\hline & & \multicolumn{9}{c}{ Variables } \\
\cline { 2 - 10 } & & RFW & LFW & SFW & RDW & LDW & SDW & LN & APL & LA \\
\hline VF & GL & $\operatorname{Pr}>$ F & Pr $>$ F & Pr $>$ F & Pr $>$ F & Pr $>$ F & Pr $>$ F & Pr $>$ F & Pr $>$ F & Pr $>$ F \\
Concentration & 4 & $0.0000^{*}$ & $0.0000^{*}$ & $0.0000^{*}$ & $0.0000^{*}$ & $0.0000^{*}$ & $0.0000^{*}$ & $0.0021^{*}$ & $0.0000^{*}$ & $0.0000^{*}$ \\
Error & 25 & - & - & - & - & - & - & - & - & - \\
Total corrected & 29 & - & - & - & - & - & - & - & - & - \\
DF (\%) & - & 30.74 & 32.55 & 25.58 & 13.56 & 26.9 & 0.18 & 20.59 & 11.36 & 24.7 \\
Average overall & - & 1.66 & 1.35 & 0.84 & 0.14 & 0.43 & 26.04 & 9.33 & 13.88 & 13667.5
\end{tabular}

Note. VF: Variation factor; CV: Coefficient of variation; DF: Degrees of freedom; RFW: Fresh weight of roots; LFW: Fresh weight of leaves; SFW: Fresh weight of stem; RDW: Dry weight of roots; LDW: Dry weight of leaves; SDW: Dry weight of stem; LN: Leaves number; APL: aerial part length; LA: leaf area. ${ }^{*}$ Significant at $5 \%$ probability of error $(\operatorname{Pr}<0.05)$.

Table 2. Results of the analysis of variance for the biochemical parameters in Luehea divaricata Martius et Zuccarini seedlings submitted to different aluminum concentrations

\begin{tabular}{llllllll}
\hline & \multicolumn{7}{c}{ Variables } \\
\cline { 2 - 7 } & & Chlorophyll a & Chlorophyll b & Totals Chlorophyll & Carotenoids & MDA & POD \\
\hline VF & GL & Pr $>$ F & Pr $>$ F & $\operatorname{Pr}>$ F & Pr $>$ F & $\operatorname{Pr}>$ F & Pr $>$ F \\
Concentration & 4 & $0.0000^{*}$ & $0.0000^{*}$ & $0.0000^{*}$ & $0.0000^{*}$ & $0.0000^{*}$ & $0.0000^{*}$ \\
Error & 25 & - & - & - & - & - & - \\
Total corrected & 29 & - & - & - & - & - & - \\
DF (\%) & - & 12.32 & 10.34 & 11.45 & 13.73 & 14.87 & 11.61 \\
Average overall & - & 1.57 & 0.51 & 3.41 & 0.44 & 0.95 & 28.41 \\
\hline
\end{tabular}

Note. VF: Variation factor; CV: Coefficient of variation; DF: Degrees of freedom; MDA: malondialdehyde; POD: guaiacol peroxidase. $*$ Significant at $5 \%$ probability of error $(\operatorname{Pr}<0.05)$. 
Figure 1 (A and B) shows the regression equations among averages observed for fresh and dry weight, both for stem, leaves and root system. The best adjusted regression to the model for all biomass analyzes was the linear regression.

The presence of aluminum (Al) in the growth medium promoted a significant reduction in both fresh and dry weight of roots, stems and leaves, presenting the lowest values in the highest concentration of $\mathrm{Al}\left(100 \mathrm{mg} \mathrm{L}^{-1}\right)$, in all analyzed variables. According to Furtini Neto et al. (1999), Al is generally the limiting factor for seedlings development and growth of some forest species, such as Senna multijuga (Cássia verrugosa/November shower), Schizolobium stans (Ipê mirim), Anadenanthera falcata (Angico do cerrado) and Cedrela fissilis (Cedro), corroborating with the obtained results in this study.
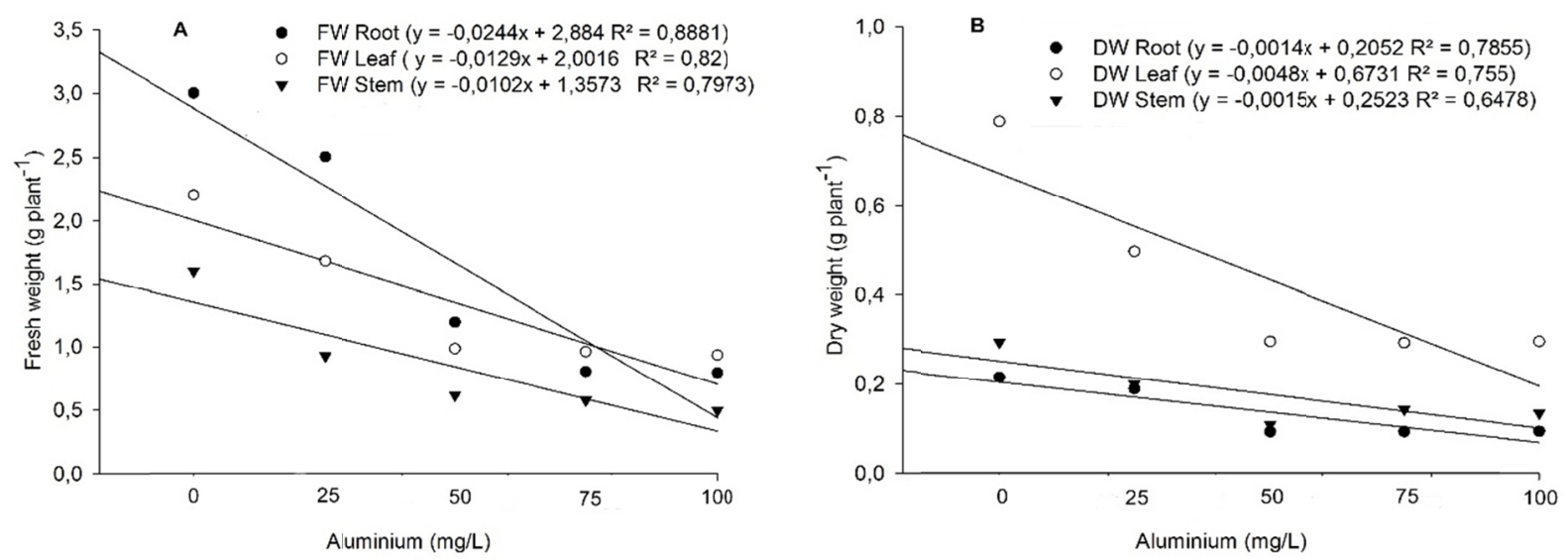

Figure 1. Fresh weight of roots (RFW), leaves (LFW) and stem (SFW) (A) and dry weight of roots (RDW), leaves (LDW) and stem (SDW) (B) in Luehea divaricata Martius et Zuccarini seedlings submitted to different aluminum concentrations

According to Silva et al. (2004), different species of the Eucalyptus genus showed to be sensitive to Al toxicity, presenting a decrease in root growth. This relation was portrayed in 15 other different forest species by Vale (1996). Since Al is a potentially reactive element with biological ligands (Singh et al., 2017), studies have suggested that inhibition of root growth caused by $\mathrm{Al}$ could be a consequence of interactions of the element with several different sites within the cell wall, plasma membrane and protoplasm (Tabaldi et al., 2009; Sun et al., 2016), once the solubilized Al in the solution first encounters the roots. Kopittke et al. (2015) reported that the primary Al lesion is apoplastic, considering that $\mathrm{Al}$, when in contact with the root system, immediately binds to outer cell walls of the root surface.

Aluminum exposure induces cell cycle deregulation, reduction of mitotic and interphase activity, leading to inhibition in cellular elongation, and possibly, as a consequence, immediate inhibition of root growth (Kochian et al., 2004; Rossiello \& Netto, 2006; Panda et al., 2009; Zelinova et al., 2011; Silva, 2012; Kopittke et al., 2015).

Because of the damages to the root system, the plant presents difficulties in the absorption of essential elements, consequently compromising its aerial part. Alves et al. (2001), when studying forest species, showed that the initial effect of Al toxicity was inhibition in root growth and development, and later progressive reduction in the shoot growth, resulting in lower root and shoot dry weight production.

Although the physiological effects of Luehea divaricata plants are also general symptoms of nutritional deficiency, it is important to emphasize that the hydroponic system allows to develop the best growth conditions, isolating the variables to be considered. Thus, it is possible to consider that the symptoms presented by the plants were not caused by a nutrient imbalance, but by the toxicity of the isolated element, $\mathrm{Al}$.

\subsection{Tolerance Index for Total Dry Weight}

The tolerance index for total dry weight of Luehea divaricata seedlings to Al toxicity generally showed a decreasing behavior with increasing element concentration, mainly from the concentration of $50 \mathrm{mg} \mathrm{L}^{-1}$ of $\mathrm{Al}$, where the tolerance index was approximately $40 \%$ (Table 3). The lower tolerance index at the intermediate dose may be related to the tolerance mechanisms of the plant. That is, a plant when exposed to Al, suffered a stress of 
the element, which led to a decrease no tolarance index. However, from the concentration of $50 \mathrm{mg} / \mathrm{L}$, with the increase in stress caused by $\mathrm{Al}$, it may also have increased the capacity of the plant to investigate defense mechanisms, a factor that resulted in the stability of the tolerance index in the highest concentrations studied.

Although the growth of the species occurs naturally in acid soils, this behavior suggests that it presents sensitivity to the element, being recommended its planting in places with low Al concentrations. Due to its low tolerance, the species has potential to be used as a signal for contaminated areas. However, $\mathrm{Al}$ concentrations employed in this study may have been higher than that found in acid soils. In addition, the use of the hydroponic system and daily adjustment of $\mathrm{pH}$ level, maintaining the constant availability of all ions to the plant, is different from what occurs in soils, factors that may have been crucial for such results.

Table 3. Tolerance index for total dry weight of Luehea divaricata Martius and Zuccarini seedlings submitted to different aluminum concentrations

\begin{tabular}{ll}
\hline Aluminum concentrations $(\mathrm{mg} / \mathrm{L})$ & Tolerance index $(\%)$ \\
\hline 0 & 100.00 \\
25 & 68.46 \\
50 & 38.46 \\
75 & 40.77 \\
100 & 40.00 \\
\hline
\end{tabular}

\subsection{Analysis of Leaves Number, Aerial Part Length and Leaf Area}

The regression equation among the observed means for leaf number, aerial part length and leaf area are presented in Figure 2, where the quadratic function was the most adjusted to the model, as for plants height the linear function was the most adjusted to the model. The Al presence in growth medium reduced all parameters evaluated in L. divaricata seedlings. In an analogous way, in an experiment carried out by Alves et al. (2001), the presence of $\mathrm{Al}$ drastically reduced the variables of the shoot of Senna multijuga and Handroanthus stans plants.

The $\mathrm{Al}$, damaging the root system of the plants, indirectly affects their absorption, translocation and transportation of nutrients to the aerial part, which can result in nutritional deficiency symptoms (phosphorus, potassium, calcium, magnesium and molybdenum) and consequent reduction of leaf area and leaf number (Poschenrieder et al., 2008). The absorption of solar radiation in these plants may be impaired, causing lower photosynthetic rates and, with this, lower accumulation of biomass, as may be observed in Figure 1. The reduction of plant growth may be due to a decrease in photosynthetic activity, which in turn may be related to both stomatal and non-stomatal factors (Konrad et al., 2005). 

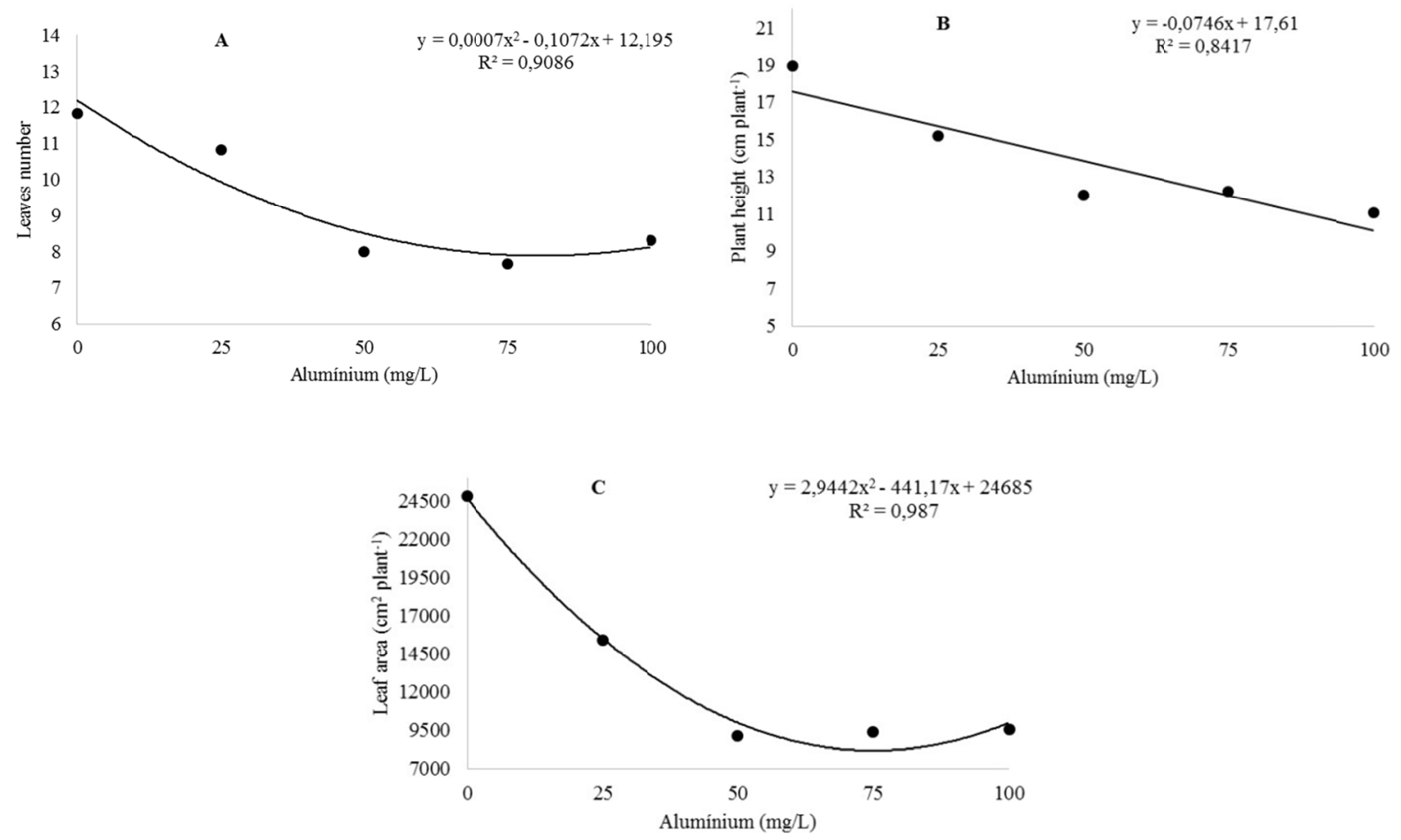

Figure 2. Leaves number (A), aerial part length (B) and leaf area (C) of Luehea divaricata seedlings Martius et Zuccarini submitted to different aluminum concentrations

\subsection{Analysis of Pigment Content}

Regarding the biochemical parameters, $\mathrm{Al}$ in the nutrient solution promoted a significant reduction both in chlorophyll $a, b$ and total content, as well as in the carotenoid content of the plants. The linear regression was the best adjusted to the model for all pigment analyzes (Figure 3), thus presenting the lowest pigment content in the highest $\mathrm{Al}$ concentration in the solution $\left(100 \mathrm{mg} \mathrm{L}^{-1}\right)$. The results of this study were similar to those reported in literature (Kuo \& Kao, 2003; Guo et al., 2007; Carlin et al., 2012).

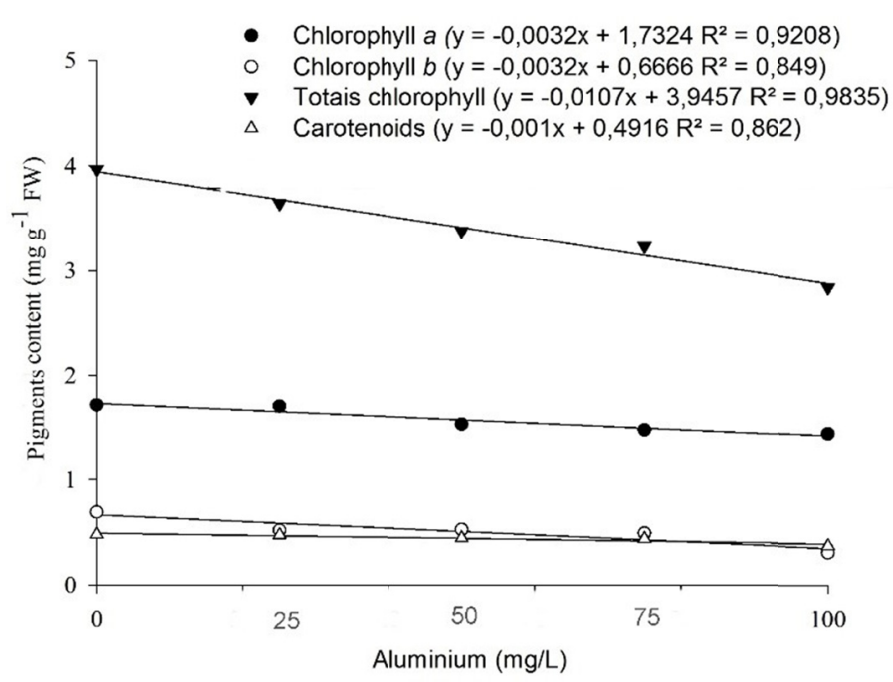

Figure 3. Chlorophyll a, b, total and carotenoids contents of Luehea divaricata Martius et Zuccarini seedlings submitted to different aluminum concentrations 
Metals which are toxic to plants, such as $\mathrm{Al}$, for generating oxidative stress, are capable of degrading aminolevulinic acid, an important enzyme component involving chlorophyll biosynthesis, thus affecting the plant photosynthetic route and consequently reducing chlorophyll content (Vajpayee et al., 2000). Similarly, Al induces carotenoid degradation in plants (Panda \& Chudhury, 2005).

The decrease of chlorophyll content may still be associated with lower plant capacity to absorb different nitrogen forms (Oliveira et al., 2017), interfering in the synthesis of photosynthetic pigments. In addition, Al toxicity impairs the absorption and translocation of magnesium, calcium and potassium, by competing for sites on cell wall and especially on the plasma membrane (Ma et al., 2014). As a consequence, the direct relationship of these elements with chlorophyll molecules may lead to a decrease in the pigment content of plants (Milivojevic \& Stojanovic, 2003).

In some species, $\mathrm{Al}$ toxicity is also related to decreased stomatal conductance and biochemical $\mathrm{CO}_{2}$ fixation reactions. This is because any environmental or biotic stress may cause changes or injuries in the formation or functional status of the thylakoid membranes of the chloroplasts, affecting electron transportation and consequently interfering directly on the $\mathrm{CO}_{2}$ assimilation rate (Peixoto et al., 2002), which can also translate into photosynthetic alteration (Konrad et al., 2005).

\subsection{Analysis of Lipid Peroxidation}

In relation to lipid peroxidation (TBARS) in the root system of $L$. divaricata plants, the linear regression was kept as the best adjusted to the model, increasing the concentration of malondialdehyde (MDA, one of the products of lipid peroxidation) with the increase in concentrations of $\mathrm{Al}$ (Figure 4). Aluminum is not a redox metal, but acts as a catalyst in the generation of reactive oxygen species (ROS) that cause oxidative stress in plants (Gupta et al., 2013). The increase in the production of ROS, such as superoxide radical $\left(\mathrm{O}_{2}^{-}\right)$, hydroxyl radical $(\mathrm{OH})$ and hydrogen peroxide $\left(\mathrm{H}_{2} \mathrm{O}_{2}\right)$, causing oxidative stress in cells, is a common consequence when plants are exposed to various biotic and abiotic stresses, including the Al toxicity (Sharma \& Dubey, 2007; Pandey et al., 2013).

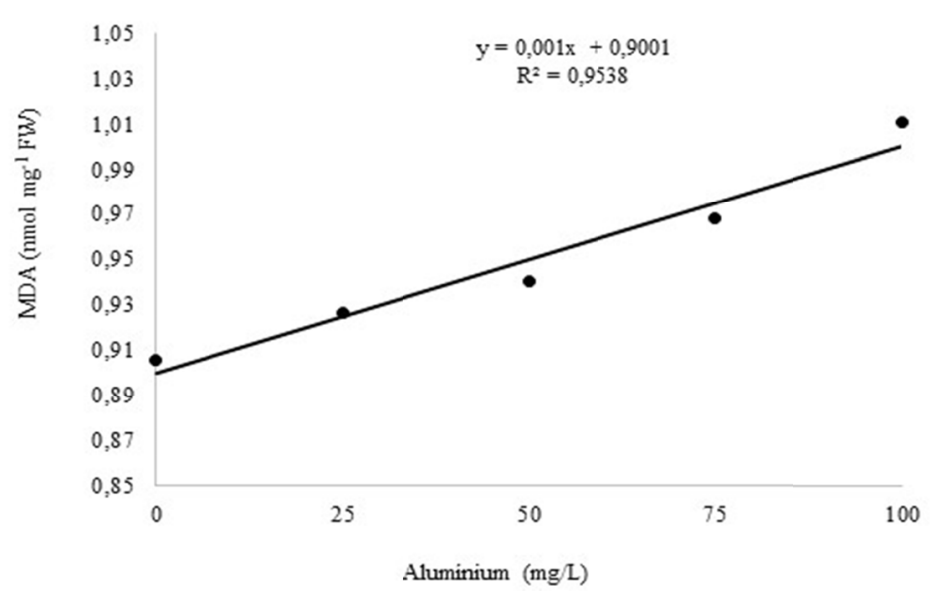

Figure 4. Lipid peroxidation in root system of Luehea divaricata Martius et Zuccarini seedlings submitted to different aluminum concentrations

The oxidative stress corresponds to a state where the pro-oxidant cellular mechanisms overcome antioxidants, obtaining the MDA as one of lipid peroxidation products. The linear increase of the MDA concentration in relation to Al concentrations shows that Luehea divaricata seedlings went through a period of stress caused by the toxicity of the element present in the nutrient solution. A similar effect of lipid peroxidation and Al toxicity was also observed by Yamamoto et al. (2001) in peas; Kuo and Kao (2003) in rice; Meriga et al. (2004) also in rice; Jin et al. (2011) in Festuca arundinacea; and Couto et al. (2012) in sunflower. ROS production may also contribute significantly to Al-induced inhibition of root elongation (Tabaldi et al., 2009), which is why it was observed the previously described reduction in fresh and dry weight of roots.

\subsection{Analysis of Enzyme Guaiacol Peroxidase in Root System}

To combat ROS, plants use a non-enzymatic antioxidant system, along with enzymatic antioxidants such as Guaiacol peroxidase (POD) and superoxide dismutase (SOD) (Silva et al., 2000; Tabaldi et al., 2009). Figure 5 
shows the regression equation for POD activity. The most adjusted regression to the model was the linear one, obtaining higher enzyme activity in the highest $\mathrm{Al}$ concentration in the nutrient solution. On the other hand, the SOD activity was not significantly influenced by different Al concentrations (data not shown).

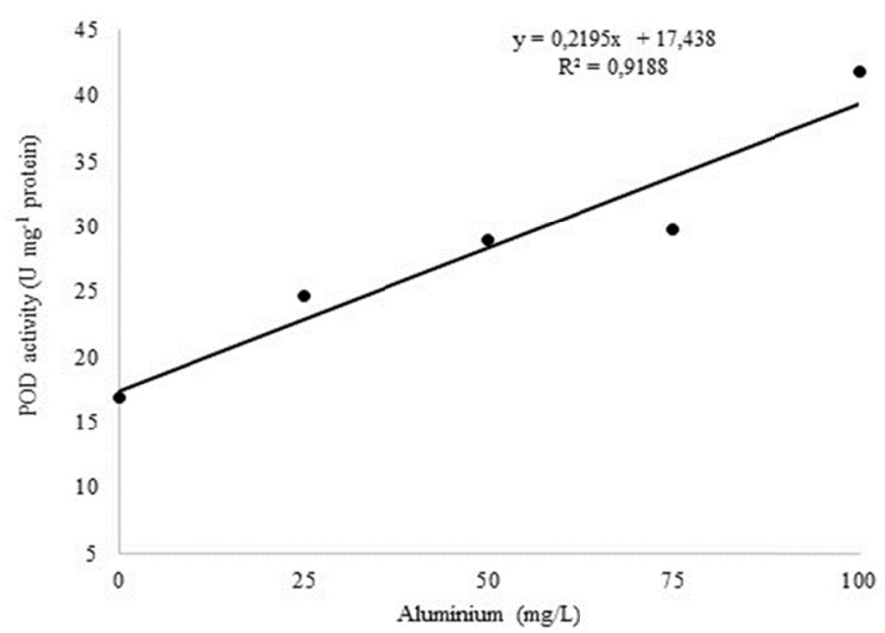

Figure 5. Enzyme guaiacol peroxidase (POD) in root system of Luehea divaricata Martius et Zuccarini seedlings submitted to different aluminum concentrations

The increase of the antioxidant activity has the purpose of alleviating the ROS lesion and helping to prevent membrane lipid peroxidation (Jin et al., 2011). The increase of POD enzyme activity due to an increase of Al concentrations occurred similarly to the increase of membrane lipid peroxidation, corroborating the attempt of the plants to reduce the oxidative stress that was shown in the presence of this element. However, the increase in POD activity was not sufficient to avoid oxidative stress, since there was a significant increase in lipid peroxidation in the plants exposed to Al. Similar studies were evidenced by Kuo and Kao (2003) in rice; Šimonovičová et al. (2004) in barley; and Guo et al. (2007) also in barley.

\section{Conclusion}

Although the species occurs naturally in acidic soils, the presence of $\mathrm{Al}$ in the growth medium for the conditions studied significantly altered both biochemical and physiological parameters in Luehea divaricata seedlings, showing a sensitive behavior of this species. Due to these characteristics, the species studied does not present phytoremediation potential and has potential to be used as a signal for contaminated areas.

\section{References}

Abreu, Jr. C. H., Muraoka, T., \& Lavorante, A. (2003). Relationship between acidity and chemical properties of Brazilian soils. Scientia Agricola, 60, 337-343. https://doi.org/10.1590/S0103-90162003000200019

Alves, R. M. M., Oliveira, L. E. M., Neto, A. E. F., \& Filho, N. D. (2001). Differential growth of the forest species Cássia-verrugosa (Senna multijuga (L.C. Rich.) I. \& B.) and Ipê-mirim (Tecoma stans H.B.K.) in the presence of aluminum. Ciência e Agrotecnologia, 25, 1161-1168. https://doi.org/10.1007/BF02370871

Bojórquez-Quintal, J. E. A., Sánchez-Cach, L. A., Ku-González, A., Santos-Briones, C., Medina-Lara, M. F., Echevarría-Machado, I., \& Muñoz-Sánchez, J. A. (2014). Differential effects of aluminum on in vitro primary root growth, nutrient content and phospholipase C activity in coffee seedlings (Coffea arabica). Journal of Inorganic Biochemistry, 134, 39-48. https://doi.org/10.1016/j.jinorgbio.2014.01.018

Bradford, M. M. (1976). A rapid and sensitive method for the quantitation of microgram quantity of protein utilizing the principle of protein-dye binding. Annals Biochemistry, 72, 248-254. https://doi.org/10.1016/ 0003-2697(76)90527-3

Brunner, I., \& Sperisem, C. (2013). Aluminum exclusion and aluminum tolerance in woody plants. Frontiers in Plant Science, 4, 1-12. https://doi.org/10.3389/fpls.2013.00172 
Carlin, S. D., Rhein, A. F. L., \& Santos, D. M. M. (2012). Simultaneous effect of water deficiency and aluminum toxicity in the soil in cultivar IAC91-5155 of sugarcane. Semina: Ciências Agrárias, 33, 553-564. https://doi.org/10.5433/1679-0359.2012v33n2p553

Carvalho, P. E. R. (2008). Espécies Arbóreas brasileiras. Embrapa Informação Tecnológica, Colombo.

Couto, C. A., Peixoto, C. P., Vieira, E. L., Carvalho, E. V., \& Peixoto, V. A. B. (2012). Action of cinetina, butyric acid and gibberellic acid on the emergency of sunflower under aluminum stress: Technical release. Comunicata Scientiae, 3, 206-209.

Dorneles, A. O. S., Pereira, A. S., Rossato, L. V., Possebom, G., Sasso, V. M., Bernardy, K., ... Tabaldi, L. A. (2016). Silicon reduces aluminum content in tissues and ameliorates its toxic effects on potato plant growth. Ciência Rural, 46, 506-512. https://doi.org/10.1590/0103-8478cr20150585

El-Moshaty, E. F. I. B., Pike, S. M., Novacky, A. J., \& Sehgal, O. P. (1993). Lipid peroxidation and superoxide production in cowpea (Vigna unguiculata) leaves infected with tobacco ring spot virus or southern bean mosaic virus. Physiol Mol Plant Pathol, 43, 109-119. https://doi.org/10.1006/pmpp.1993.1044

FAO, \& IIASA. (2007). Mapping Biophysical Factors that Influence Agricultural Production and Rural Vulnerability. Rome: FAO \& IIASA.

Ferreira, D. F. (2011). Sisvar: A computer statistical analysis system. Ciência Agrotec, 35, 1039-1042. https://doi.org/10.1590/S1413-70542011000600001

Foy, C. D., Chaney, R. L., \& White, M. C. (1978). The physiology of metal toxicity in plants. Annual Review of Plant Physiology, 29, 511-566. https://doi.org/10.1146/annurev.pp.29.060178.002455

Furtini Neto, A. E., Resende, A. V., Vale, F. B., Faquin, V., Fernandes, L. A. (1999). Soil acidity, growth and mineral nutrition of some tree species at seedling phase. Cerne, 5, 01-12. https://doi.org/10.21475/ajcs.17. 11.10.pne599

Giannopolitis, C. N., \& Ries, S. K. (1977). Purification and quantitative relationship with water-soluble protein in seedlings. Journal of Plant Physiology, 48, 315-318. https://doi.org/10.1104/pp.59.2.315

Guo, T. R., Zhang, G. P., \& Zhang, Y. H. (2007). Physiological changes in barley plants under combined toxicity of aluminum, copper and cadmium. Colloids and Surfaces B: Biointerfaces, 57, 182-188. https://doi.org/10.1016/j.colsurfb.2007.01.013

Gupta, N., Gaurav, S. S., \& Kumar, A. (2013). Molecular basis of aluminium toxicity in plants: A Review. American Journal of Plant Sciences, 4, 21-37. https://doi.org/10.4236/ajps.2013.412A3004

Hiscox, J. D., \& Israelstam, G. F. (1979). A method for the extraction of chlorophyll from leaf tissue without maceration. Canadian Journal of Botany, 57, 1132-1334. https://doi.org/10.1139/b79-163

IBGE (Instituto Brasileiro de Geografia e Estatística). (2012). Manual técnico da vegetação brasileira, Rio de Janeiro (Vol. 1, pp. 1-271).

Jin, S. H., Li, X. Q., \& Jia, X. L. (2011). Genotypic Differences in the Responses of Gas Exchange, Chlorophyll Fluorescence, and Antioxidant Enzymes to Aluminum Stress in Festuca arundinacea. Russian Journal of Plant Physiology, 58, 560-566. https://doi.org/10.1134/S102144371103006X

Kochian, L. V., Hoekenga, O. A., \& Piñeros, M. A. (2004). How do crop plants tolerate acid soils? Mechanisms of aluminum tolerance and phosphorous efficiency. Annual Review Plant Biology, 55, 459-493. https://doi.org/10.1146/annurev.arplant.55.031903.141655

Konrad, M. L. F., Silva, J. A. B., Furlani, P. R., \& Machado, E. C. (2005). Gas exchange and chlorophyll fluorescence in six coffee cultivars under aluminum stress. Bragantia, 64, 339-347. https://doi.org/10.1590/ S0006-87052005000300004

Kopittke, P. M., Moore, K. L., Lombi, E., Gianoncelli, A., Ferguson, B. J., Blamey, F. P. C., ... Tollenaere, A. (2015). Identification of the primary lesion of toxic aluminum in plant roots. Plant Physiology, 167, 1402-1411. https://doi.org/10.1104/pp.114.253229

Kuo, M. C., \& Kao, C. H. (2003). Aluminium effects on lipid peroxidation and antioxidative enzyme activities in rice leaves. Biologia plantarum, 46, 149-152. https://doi.org/10.1023/A:1022356322373

Lichtenthaler, H. K. (1987). Chlorophylls and carotenoids-pigments of photosynthetic biomembranes. Methods Enzymology, 148, 350-382. https://doi.org/10.1016/0076-6879(87)48036-1 
Ma, J. F., Chen, Z. C., \& Shen, R. F. (2014). Molecular mechanisms of Al tolerance in gramineous plants. Plant Soil, 381, 1-12. https://doi.org/10.1007/s11104-014-2073-1

Meriga, B., Reddy, B. K., Rao, K. R., Reddy, L. A., \& Kishor, P. B. (2004). Aluminium-induced production of oxygen radicals, lipid peroxidation and DNA damage in seedlings of rice (Oryza sativa). Journal Plant Physiology, 161, 63-68. https://doi.org/10.1078/0176-1617-01156

Milivojevic, D. B., \& Stojanovic, D. D. (2003). Role of calcium in aluminum toxicity on content of pigments and pigment-protein complexes of soybean. Journal of Plant Nutrition, 26, 341-350. https://doi.org/ 10.1081/PLN-120017140

Oliveira, H. C., da Silva, L. M., de Freitas, L. D., Debiasi, T. V., Marchiori, N. M., Aidar, M. P., ... Stolf-Moreira, R. (2017). Nitrogen use strategies of seedlings from neotropical tree species of distinct successional groups. Plant Physiology and Biochemistry, 114, 119-127. https://doi.org/10.1016/j.plaphy. 2017.03 .003

Panda, S. K., \& Choudhury, S. (2005). Chromium stress in plants. Brazilian Journal Plant Physiology, 17, 95-102. https://doi.org/10.1590/S1677-04202005000100008

Panda, S. K., Baluška, F., \& Matsumoto, H. (2009). Aluminum stress signalling in plants. Plant Signaling Behavior, 4, 592-597. https://doi.org/10.4161/psb.4.7.8903

Pandey, P., Srivastava, R. K., \& Dubey, R. S. (2013). Salicylic acid alleviates aluminum toxicity in rice seedlings better than magnesium and calcium by reducing aluminum uptakes up pressing oxidative damage and increasing antioxidative defense. Ecotoxicology, 22, 656-670. https://doi.org/10.3389/fchem.2017. 00096

Peixoto, H. P., Matta, F. M., \& Matta, J. C. (2002). Responses of the photosynthetic apparatus to aluminum stress in two sorghum cultivars. Journal of Plant Nutrition, 25, 821-832. https://oi.org/10.1081/ PLN-120002962

Poschenrieder, C., Gunsé, B., Corrales, I., \& Barceló, J. (2008). A glance into aluminium toxicity and resistance in plants. Science of the Total Environment, 400, 356-368. https://doi.org/10.1016/j.scitotenv.2008.06.003

Rossiello, R. O. P., \& Netto, J. J. (2006). Toxidez de alumínio em plantas: Novos enfoques para um velho problema. In M. S. Fernandes (Ed.), Nutrição Mineral de Plantas (pp. 375-418). Vicosa.

Schmitt, M., Watanabe, T., \& Jansen, S. (2016). The effects of aluminium on plant growth in a temperate and deciduous aluminium accumulating species. AoB Plants, 8, 1-13. https://doi.org/10.1093/aobpla/plw065

Sharma, P., \& Dubey, R. S. (2007). Involvement of oxidative stress and role of antioxidative defense system in growing rice seedlings exposed to toxic concentrations of aluminum. Plant Cell Reports, 26, 2027-2038. https://doi.org/10.1007/s00299-007-0416-6

Silva, I. R., Novais, R. F., Jham, G. N., Barros, N. F., Gebrim, F. O., Nunes, F. N., ... Leite, F. P. (2004). Responses of eucalypt species to aluminum: the possible involvement of low molecular weight organic acids in the Al tolerance mechanism. Tree Physiology, 24, 1268-1277. https://doi.org/10.1093/treephys/ 24.11.1267

Silva, I. R., Smyth, T. J., Moxley, D. F., Carter, T. E., Allen, N. S., \& Rufty, T. W. (2000). Aluminum accumulation at nuclei of cells in the root tip. Fluorescence detection using lumogallion and confocal laser scanning microscopy. Plant Physiology, 123, 543-552. https://doi.org/10.1104/pp.123.2.543

Silva, S. (2012). Aluminium toxicity targets in plants. American Journal of Botany, 2012, 1-8. https://doi.org/ $10.1155 / 2012 / 219462$

Šimonovičová, L. M., Tamás, L., Huttová, J., \& Mistrík, I. (2004). Effect of aluminium on oxidative stress related enzymes activities in barley roots. Biologia Plantarum, 48, 261-266. https://doi.org/10.1023/B:BIOP. $0000033454.95515 .8 \mathrm{a}$

Singh, S., Tripathi, D. K., Singh, S., Sharmam S., Dubey, N. K., Chauhan, D. K., \& Vaculík, M. (2017). Toxicity of aluminium on various levels of plant cells and organism: A review. Environmental and Experimental Botany, 137, 177-193. https://doi.org/10.1016/j.envexpbot.2017.01.005

Sousa, A., Abd Elgawad, H., Han, A., Teixeira, J., Matos, M., \& Fidalgo, F. (2016). Oxidative Metabolism of Rye (Secale cereale L.) after Short Term Exposure to Aluminum: Uncovering the Glutathione-Ascorbate Redox Network. Frontiers in plant Science, 7, 685-692. https://doi.org/10.3389/fpls.2016.00685 
Sun, C., Lu, L., Yu, Y., Liu, L., Hu, Y., Ye, Y., Jin, C., \& Lin, X. (2016). Decreasing methylation of pectin caused by nitric oxide leads to higher aluminium binding in cell walls and greater aluminium sensitivity of wheat roots. Journal of Experimental Botany, 67, 979-989. https://doi.org/10.1093/jxb/erv514

Tabaldi, L. A., Castro, G. Y., Cargnelutti, D., Skrebsky, E. C., Gonçalves, J. F., Rauber, R., ... Nicoloso, F. T. (2009). Micronutrient concentration in potato clones with distinct physiological sensitivity to Al stress. Ciência Rural, 39, 379-385. https://doi.org/10.1590/S0103-84782008005000065

Trannin, I. C. B., Moreira, F. M. S., Siqueira, J. O., \& Lima, A. (2001). Tolerance of Bradyrhizobium and Azorhizobium strains and isolates to copper, cadmium and zinc "in vitro". Revista Brasileira de Ciência do Solo, 25, 305-316. https://doi.org/10.1590/S0100-06832001000200007

Vajpayee, P., Tripathi, R. D., Rai, U. N., Ali, M. B., \& Singh, S. N. (2000). Chromium accumulation reduces chlorophyll biosynthesis, nitrate reductase activity and protein content of Nymphaea alba. Chemosphere, 41, 1075-1082. https://doi.org/10.1016/S0045-6535(99)00426-9

Vale, F. R. (1996). Crescimento radicular de espécies florestais em solo ácido. Pesquisa Agropecuária Brasileira, 31, 609-616.

Yamamoto, Y., Kobayashi, Y., \& Matsumoto, H. (2001). Lipid Peroxidation Is an Early Symptom Triggered by Aluminum, But Not the Primary Cause of Elongation Inhibition in Pea Roots. Plant Physiology, 125, 199-208. https://doi.org/10.1104/pp.125.1.199

Zelinová, V., Halušková, L., Huttová, J., Illéš, P., Mistrík, I., Valentovičová, K., \& Tamás, L. (2011). Short-term aluminium-induced changes in barley root tips. Protoplasma, 248, 523-530. https://doi.org/10.1007/ s00709-010-0199-4

Zeraik, A. E., Souza, F. S., \& Fatibello-Filho, O. (2008). Development of a spot test for peroxidase activity monitoring during a purification procedure. Química Nova, 31, 731-734. https://doi.org/10.1590/S010040422008000400003

Zhu, Z., Wei, G., Li, J., Qian, Q., \& Yu, J. (2004). Silicon alleviates salt stress and increases antioxidant enzymes activity in leaves of salt-stressed cucumber (Cucumis sativus L.). Plant Science, 167, $527-533$. https://doi.org/10.1016/j.plantsci.2004.04.020

\section{Copyrights}

Copyright for this article is retained by the author(s), with first publication rights granted to the journal.

This is an open-access article distributed under the terms and conditions of the Creative Commons Attribution license (http://creativecommons.org/licenses/by/4.0/). 